\title{
Lamprodila mirifica (Mulsant, 1855) (Buprestidae: Chrysochroinae: Poecilonotini) - new for the fauna of Poland. Key to the identification of Polish species of the genus Lamprodila Motschulsky, 1860
}

\author{
Adam BYK* and Tomasz MOKRZYCKI** \\ Department of Forest Protection and Ecology, Warsaw University of Life Sciences - SGGW, Nowoursynowska 159/34, \\ 02-776 Warszawa, Poland; *adam_byk@sggw.pl, **tomasz_mokrzycki@sggw.pl

\begin{abstract}
The paper introduces Lamprodila mirifica (Mulsant, 1855) as a beetle new for the Polish fauna. This is a monophagous species whose larvae develop under bark of branches and trunks of elms, preferably well insolated. It was recently found on the Wiekopolsko-Kujawska Lowland, in Krajkowo near Poznan - hitherto the only locality in Poland and the northernmost in Europe. A key to the identification of Polish species of Lamprodila Motschulsky, 1860 is provided.
\end{abstract}

Key words: Coleoptera, Lamprodila mirifica, elm, fauna of Poland

INTRODUCTION

Lamprodila Motschulsky, 1860

Lampra Lacordaire, 1835

Scintillatrix Obenberger, 1956

The genus Lamprodila is represented in Palaearctis by 40 species classified in two subgenera:

- $\quad$ subgenus Lamprodila s. str., with 20 species, 7 of them in Europe,

- subgenus Palmar Schaefer, 1949, with 20 species, 3 of them in Europe (Kubán 2006).

Species of the genus Lamprodila were often placed in the genera: Lampra, Ovalisia, Palmar and Scintillatrix (Zykov 1999).

The taxa occurring in Poland - Lamprodila decipiens decipiens (Gebler, 1847), Lamprodila mirifica mirifica (Mulsant, 1855) and Lamprodila rutilans rutilans (Fabricius, 1777 ) - belong to the subgenus Lamprodila. Pronotum and elytra of these beetles are green or greenish-blue with distinct metallic shine; elytral sides often with reddish-golden or cupreous tint. Elytral interstriae with small, black, usually elongated spots of smooth and slightly convex surface. Puncturation sparser along suture, more dense on sides. Scutellum much wider than long.

In Poland imagines of the genus Lamprodila can be found from May to August on leaves, branches and trunks of their host-plants. They are most active at midday. Larvae develop under bark of branches and trunks of lime, elm, and willow trees (Richter 1952, Hellrigl 1972, Harde 1979, Burakowski et al. 1985, Bílý 2002). Larval development lasts for 2, exceptionally 3 years (Bílý 1989, 2002). Larvae of Lamprodila decipiens and $L$. rutilans was described by Zykov (1983). 


\section{DISTRIBUTION AND BIONOMY}

\section{Lamprodila decipiens (Gebler, 1847)}

dives Guillebeau, 1889 (Poecilonota)

modesta Guillebeau, 1889 (Poecilonota)

The subspecies Lamprodila decipiens decipiens (Gebler, 1847) occurs in Europe (from the Pyrenees to Ural, except British Isles, Iceland and Scandinavia), in Kazakhstan, Turkmenia and Siberia. The subspecies Lamprodila decipiens achaica (Brandl, 1986) has been reported only from Greece, while the subspecies Lamprodila decipiens kamikochiana (Obenberger, 1940) from the Far East and Japan.

In Poland Lamprodila decipiens occurs probably at the entire territory of Poland with the exception of high mountains, although it has been actually recorded from few widely spaced localities only. Adults appear from May to the last days of July. Larvae develop under bark of branches and trunks of willows, most frequently sallows (Salix caprea L.). Larval tunnels in cambium and phloem are short and irregular, sometimes slightly marked in the upper layers of xylem. Pupal chamber bored into external layers of sapwood to the depth of $3 \mathrm{~cm}$.

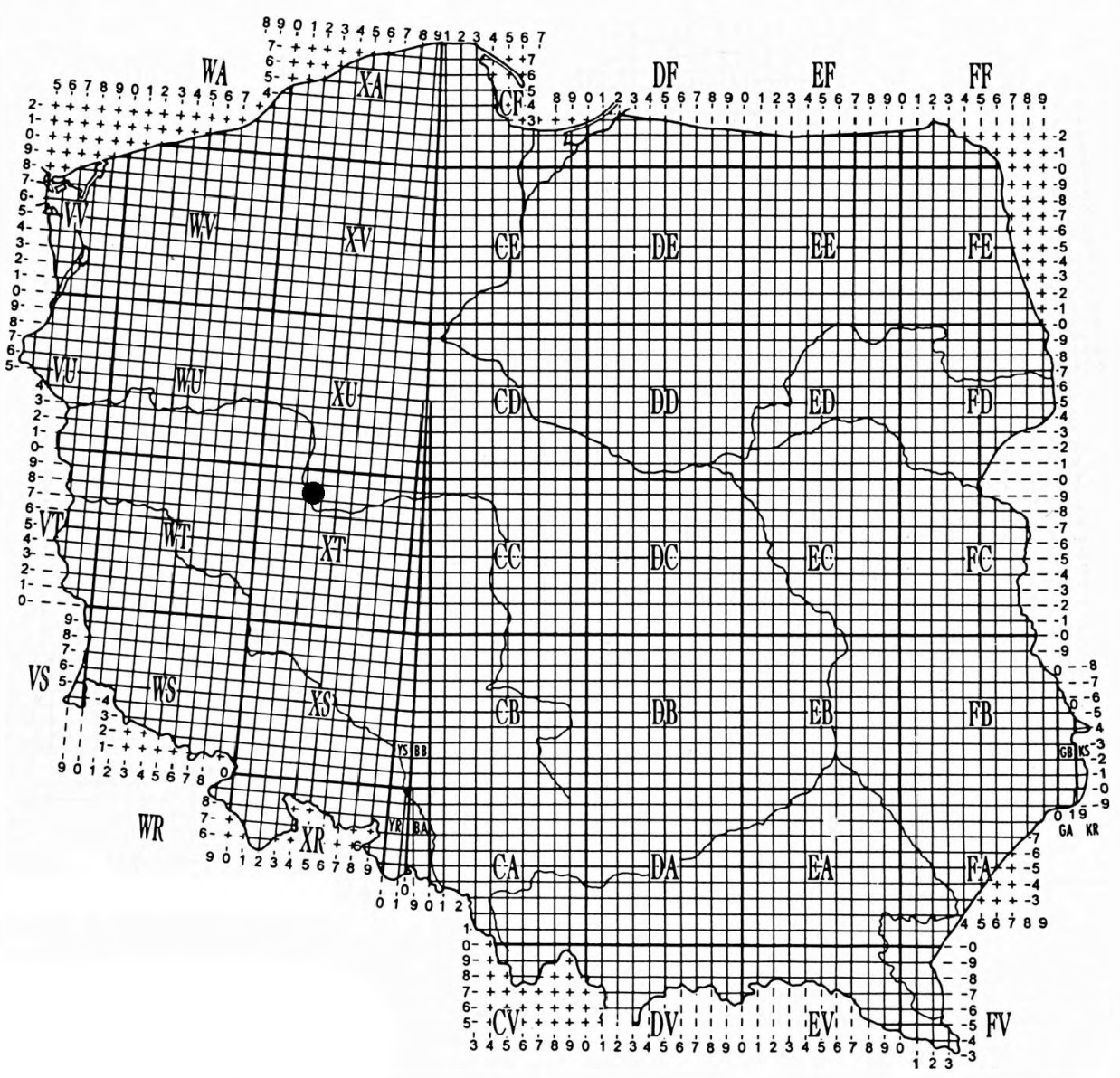

Fig. 1. The locality of Lamprodila mirifica (Mulsant, 1855) in Poland (Wielkopolsko-Kujawska Lowland: Krajkowo near Poznań - UTM XT38). 


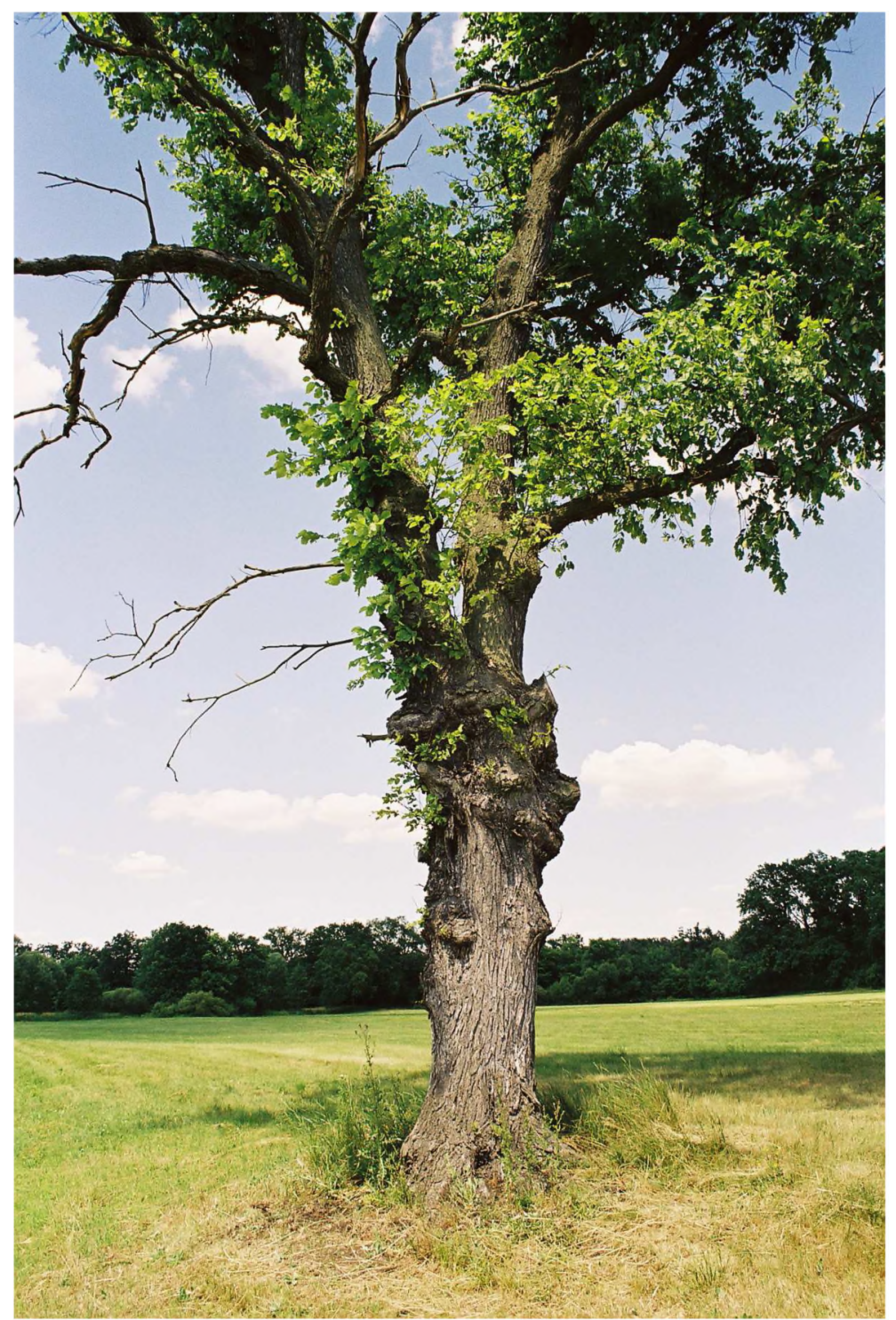

Fig. 2. Field elm-tree (Ulmus minor Mill.) infested by Lamprodila mirifica (Mulsant, 1855) (Poland: WielkopolskoKujawska Lowland: Krajkowo near Poznań (UTM XT38))

\section{Lamprodila rutilans (Fabricius, 1777)}

aeruginosa Herbst, 1780 (Buprestis)

fastuosa Well, 1781 (Buprestis)

gemmea Voet. 1806 (Cucujus)

The subspecies Lamprodila rutilans rutilans (Fabricius, 1777) inhabits almost all Europe (though hitherto has not been found on the British Isles and Iceland) and Algeria. The subspecies Lamprodila rutilans podolica (Obenberger, 1952) was reported from Ukraine and European part of Russia. 


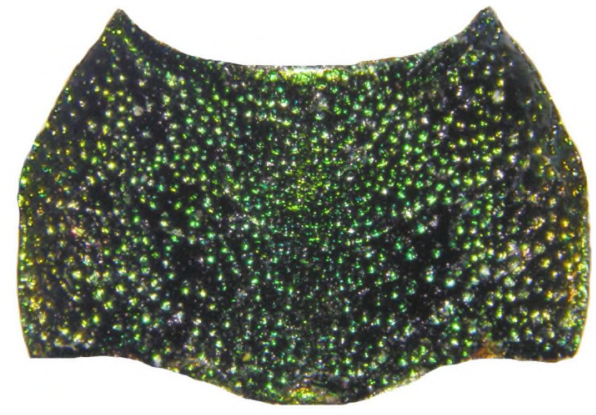

Fig. 3. Pronotum of Lamprodila rutilans (Fabricius, 1777)

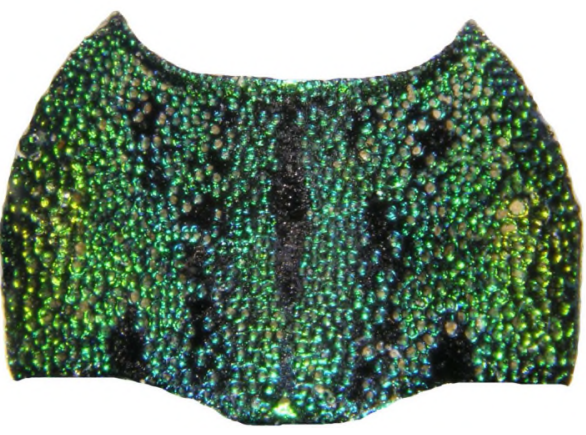

Fig. 5. Pronotum of Lamprodila decipiens (Gebler, 1847)

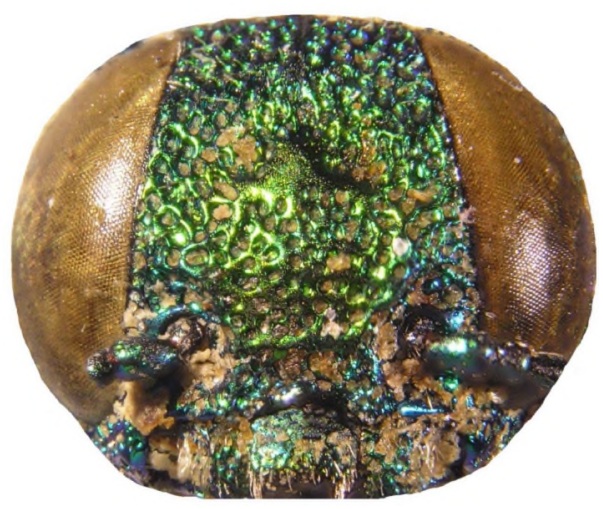

Fig. 7. Head of Lamprodila decipiens (Gebler, 1847)

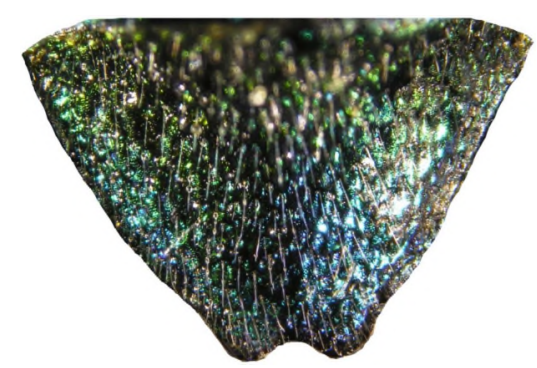

Fig. 4. Last abdominal sternite of Lamprodila rutilans (Fabricius, 1777)

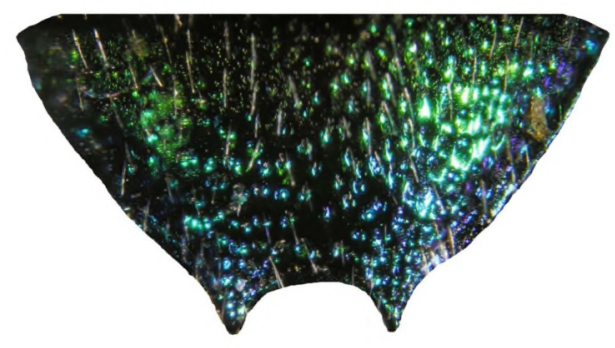

Fig. 6. Last abdominal sternite of Lamprodila decipiens (Gebler, 1847)

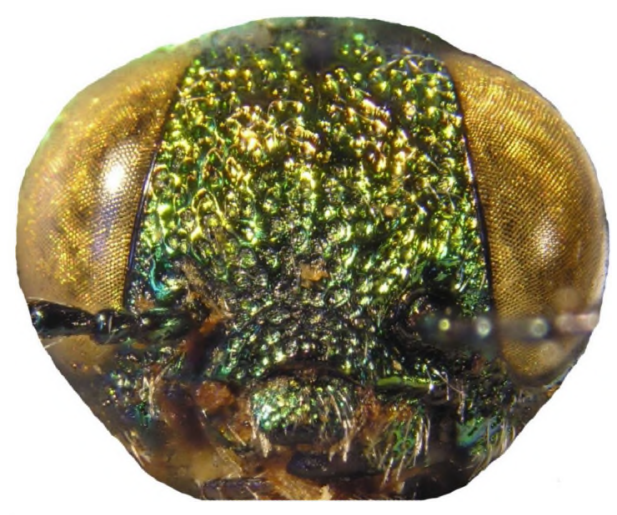

Fig. 8. Head of Lamprodila mirifica (Mulsant, 1855) 
Lamprodila rutilans is in Poland distributed probably all-over the country, but has been recorded from but relatively not numerous, sparse localities. The beetles can be met from May to the end of July. Larvae develop under bark and in phloem of trunks and thick branches of old lindens, rarely in young trees. Short irregular larval galleries are gnawed in phloem, cambium, and outer layers of xylem. Pupal chamber is situated in the bark.

\section{Lamprodila mirifica (Mulsant, 1855)}

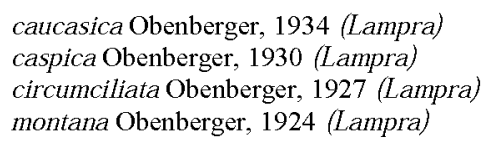

The subspecies Lamprodila mirifica mirifica (Mulsant, 1855) occurs in Albania, Austria, Bosnia Herzegovina, Bulgaria, Belarus?, Croatia, Czech Republic, France, Germany, Great Britain, Hungary, Italy, Macedonia, Moldova, Poland, Portugal, Romania, Slovakia, Slovenia, Spain, Russia (South European Territory), Serbia and Montenegro, Ukraine, Kazakhstan and Turkey. The subspecies Lamprodila mirifica barbarica (Hellrigl, 1972) has been known only from Algeria, the subspecies Lamprodila mirifica nadezhdae (Semenov, 1909) from Azerbaijan, Armenia, Georgia, Iran and Turkmenia, while the subspecies Lamprodila mirifica vicina (Guillebeau, 1889) inhabits Azerbaijan, Iran, Turkey and Syria.

Adults fly from May to July and feed with leaves of elms (Maslov 1970).

Larvae develop under bark of branches and trunks of elms. Larval galleries short, irregular, run in cambium and phloem, sometimes slightly penetrate external layers of xylem.

\section{DISCUSSION}

Lamprodila mirifica was cited (without any details) by Bílý (2002) and Kubán̆ (2006), but these informations have not been supported with any evidence. Recently it was found in Krajkowo near Poznan (Fig. 1) and this is for the moment the only locality of this species in Poland:

Wiekopolsko-Kujawska Lowland: Krajkowo near Poznań (UTM XT38), 4-5 VII 2005, 11 exx., leg. Borowski J., Byk A. and Mokrzycki T.

This locality lies within the Rogalin Landscape Park in the Warta Valley and is the northernmost point of the species distribution area in Europe.

The Rogalin Landscape Park extends over 12640 ha. It includes two Nature Reserves: "Krajkowo" and "Goździk siny w Grzybnie". The main objects of protection are numerous old river beds and, in the Warta Valley, one of the largest in Europe agglomerations of old oak-trees. Peculiar microclimate of this area provides appropriate conditions for the development of rare thermophilous insects of the family Buprestidae: Agrilus graminis Castelnau et Gory, 1839 (Mokrzycki et al. 2008), A. obscuricollis Kiesenwetter, 1857 (Przewoźny 2007, Mokrzycki et al. 2008), A. suvorovi Obenberger, 1935 (Przewoźny 2007), Coraebus undatus (Fabricius, 1787) (Mokrzycki et al. 2008), Eurythyrea quercus (Herbst, 1780) (Gutowski 2004, Przewoźny 2007, Mokrzycki et al. 2008.) and Dicerca alni (Fischer von Waldheim, 1824).

Imagines of Lamprodila mirifica have been observed in sunny midday, flying at a decaying field elm-tree (Ulmus minor Mill.) on mowed meadow (Fig. 2). The meadow grows on riverine silt, getting very warm during strong insolation, what results in peculiar microclimate favourable to the occurrence of this thermophilous jewel-beetle. Observed were pairs in copula as well as ovipositing females. 
The extensive farming hitherto conducted on this area has assured the survival of rare thermophilous species of jewel beetles. Mowing of meadows around trees prevents succession and consequent change of microclimatic conditions (temperature, humidity, degree of insolation). Not cultivated river valleys play an extraordinarily important role of the dispersion tracks for insects (Sienkiewicz \& Konwerski 2004, 2007; Mokrzycki et al. 2008), enabling some southern species to migrate far north. And this is the explanation for the occurrence of Lamprodila mirifica on that place.

\section{KEY TO THE IDENTIFICATION OF POLISH SPECIES OF LAMPRODILA MOTSCHULSKY, 1860}

1. Pronotum without black longitudinal median line or slightly convex black spots (Fig. 3). Last abdominal sternite with a pair of narrowly separated, blunt and short outgrowths (Fig. 4). Black elytral spots sparse. Body length 11-15 mm

Lamprodila rutilans (Fabricius, 1777)

- Pronotum with distinct black longitudinal median line and slightly convex black spots (Fig. 5). Apex of last abdominal sternite with widely separated long, sharp outgrowths (Fig. 6). Elytra with more numerous dark spots................................................................... 2

2. Fourth antennomere at least by $1 / 3$ longer than third. Front with small smooth tubercle (Fig. 7). Elytral interstriae convex and densely punctured. Body length $12-16 \mathrm{~mm}$.

Lamprodila decipiens (Gebler, 1847)

- Fourth antennomere at most by $1 / 4$ longer than third. Front without smooth tubercle (Fig. 8).

Elytral interstriae flat and less densely punctured. Body length $8-16 \mathrm{~mm}$

Lamprodila mirifica (Mulsant, 1855)

\section{REFERENCES}

Bílý S. 1989. Krascovití. Buprestidae. Zoologické klíče. Academia/Praha: 111 pp.

BÍÝ S. 2002. Summary of the bionomy of the Buprestid beetles of Central Europe (Coleoptera: Buprestidae). Acta Entomologica Musei Nationalis Pragae, Suppl. 10: 1-104.

Burakowski B., MroczKowski M. \& STEFANSKA J. 1985. Buprestoidea, Elateroidea i Cantharoidea. Chrząszcze Coleoptera. Katalog Fauny Polski, XXIII, 10. PWN, Warszawa. 402 pp.

GuTowski J. M. 2004. Eurythyrea quercus (Herbst) - Pysznik dębowiec. In: GŁOWACIŃski Z. \& NowaCKI J. (eds), Polish Red Data Book of Animals - Invertebrates. Instytut Ochrony Przyrody PAN w Krakowie, Akademia Rolnicza im. A. Cieszkowskiego w Poznaniu: 106-107. [In Polish with English summary]

HARDE K. W. 1979. Familie: Buprestidae (Prachtkäfer), pp. 204-248. In: FREUdE H., HARDE K. W. \& LOHSE G. A. (eds), Die Käfer Mitteleuropas. Band 6. Goecke \& Evers, Krefeld. 368 pp.

HELLRIGL K. G. 1972. Revision der westpaläarktischen Arten der Prachtkäfergattung Lampra Lac., (Col., Buprestidae). Annalen des Naturhistorischen Museums in Wien, 76: 649-708.

KUBÁN V. 2006. Poecilonotini, pp. 350-352. In: LÖBL I. \& SMETANA A. (eds): Catalogue of Palaearctic Coleoptera, Vol. 3. Stenstrup: Apollo Books, 690 pp.

MASLOV A. D. 1970. Vrediteli il'movykh porod i mery borby s nimi. Izd. Lesnaja promyshlennost. Moskva, 70pp.

MOKRZYCKI T, BYK A. \& BOROWSKI J. 2008. Rare and relict saproxylic beetles (Coleoptera) of old oaks of the Rogalin Landscape Park. Parki Narodowe i Rezerwaty Przyrody, 27(4): 43-56. [In Polish with English summary]

PRZEWOŹNY M. 2007. New for the Wielkopolska-Kujawy Lowland and rare species of jewel beetles (Coleoptera: Buprestidae). Wiadomości Entomologiczne, 26 (1): 59-60. [In Polish]

RTCHTER A. A. 1952. Fauna SSSR, 13, 4. Zlatki (Buprestidae) II. Izdatel'stvo AN SSSR, Moskva-Leningrad, 234 pp.

SIENKIEWICZ P. \& KONWERSKI S. 2004. The importance of "Krajkowo" nature reserve in protection of beetles (Coleoptera) of river valley environments. Wiadomości Entomologiczne, 23, suppl. 2: 189-191. [In Polish]

SIENKIEWICZ P. \& KONWERSKI S. 2007. Rare and endangered beetles (Coleoptera) from Krajkowo Nature Reserve in the middle course of the Warta river in Western Poland (pp. 57-63). In: SKLODOWSKI J., HURUK S., BARAŠEVSKIS A. \& TARASIUK S. (eds), Protection of Coleoptera in the Baltic Sea Region. Warsaw Agricultural University Press, $240 \mathrm{pp}$.

ZYKov I. YE. 1983. Liczinki zlatok Lampria decipiens Gebl. i L. rutilans F. (Coleoptera, Buprestidae). Entomologicheskoe Obozrenie 62 (4):737-745.

ZYKOV I.YE. 1999. Reviziya zlatok roda Palmar Schaefer (Coleoptera, Buprestidae) fauny SNG i sopredel'nyh stran. I. Obzor vidov. Entomologicheskoe Obozrenie 78 (1): 101-121. 


\section{STRESZCZENIE}

[Lamprodila mirifica (Mulsant, 1855) (Buprestidae: Chrysochroinae: Poecilonotini) - nowy gatunek dla fauny Polski. Klucz do oznaczania polskich gatunków z rodzaju Lamprodila Motschulsky, 1860]

Praca dotyczy występowania nowego dla fauny Polski gatunku chrząszcza Lamprodila mirifica (Mulsant, 1855). Jest to gatunek monofagiczny, którego larwy żerują pod kora galęzi i pni wiązów. Preferuje on stanowiska mocno nasłonecznione. Z Polski Lamprodila mirifica została ogólnikowo podana przez Bílý (2002) i Kubán (2006). Jednakże informacje te nie zostaly poparte żadnym materialem dowodowym. Gatunek ten zostal niedawno znaleziony na Nizinie Wiekopolsko-Kujawskiej w Krajkowie koło Poznania i jest to, jak dotad, jedyne jego stanowisko w Polsce. Położone jest w dolinie Warty na obszarze Rogalińskiego Parku Krajobrazowego i w Europie jest najdalej wysunięte na północ. Do pracy dolączony jest klucz do oznaczania krajowych gatunków z rodzaju Lamprodila. 